\title{
Disease Resistance and Biomass Stability of Forage Pearl Millet Hybrids with Partial Rust Resistance
}

\author{
J. P. Wilson and R. N. Gates, USDA-ARS Forage and Turf Research Unit, University of Georgia Coastal Plain \\ Experiment Station, Tifton 31793-0748
}

\begin{abstract}
Wilson, J. P., and Gates, R. N. 1999. Disease resistance and biomass stability of forage pearl millet hybrids with partial rust resistance. Plant Dis. 83:733-738.

The expression of partial resistance to Puccinia substriata var. indica and its contribution to digestible biomass production in forage pearl millet hybrids were evaluated in field experiments at Tifton, GA. Inbreds Tift 383, Tift 65, and nine inbreds with partial resistance selected from the cross Tift $383 \times$ 'ICMP 501' were crossed to Tift $23 \mathrm{DA}_{4}$. The parental inbreds and hybrids were evaluated in natural epidemics in 1996 and 1997. Because of maturity differences among the lines, slope of the regression of logit rust severity on time (apparent infection rate) and area under the disease progress curve (AUDPC) calculated for a defined interval of plant growth (10 days before to 20 days after anthesis) and adjusted for initial rust severity at 10 days prior to anthesis were the most useful indicators of resistance. Inbred resistance was not a reliable predictor of hybrid resistance when evaluated by either variable. Hybrids were evaluated for biomass production in 1996 and 1997 in a split-plot design, with hybrids as main plots and nontreated or chlorothalonil fungicide-treated as subplots. Differences existed among hybrids for AUDPC and for digestible dry matter yield (DDMY) and its components. Over all hybrids, the response between DDMY and final rust severity was described by logarithmic regression. Two clusters of hybrids were identified by cluster analysis of disease-related data from both experiments. The cluster of susceptible hybrids tended to have a lower DDMY and were less stable over year $\times$ treatment environments than the cluster of partially resistant hybrids. Lodging in nontreated plots in 1997 primarily occurred in susceptible hybrids. Although resistance was expressed in certain hybrids, greater levels of partial resistance are needed to provide adequate protection against DDMY losses.
\end{abstract}

Genetic resistance is among the most practical and cost-effective options for disease control in many crops. Implementing resistance gene deployment strategies that provide effective crop protection can be guided by information of the relationship between yield and disease. In forage pearl millet (Pennisetum glaucum (L.) R. Br.), highly effective, often race-specific, resistance is desirable since low levels of rust infection caused by Puccinia substriata Ellis \& Barth. var. indica Ramachar \& Cummins result in significant losses of digestible dry matter yield (DDMY) (15). However, the population of $P$. substriata var. indica in the United States is pathogenically diverse (11), which will hamper efforts to breed for stable disease resistance and biomass production in pearl millet since race-specific

Corresponding author: J. P. Wilson

E-mail: jwilson@tifton.cpes.peachnet.edu

Cooperative investigation of the USDA-ARS and the University of Georgia, College of Agriculture and Environmental Sciences, Agricultural Experiment Stations.

Accepted for publication 5 April 1999.

Publication no. D-1999-0618-02R

This article is in the public domain and not copyrightable. It may be freely reprinted with customary crediting of the source. The American Phytopathological Society, 1999. resistance tends to be short lived. Alternative strategies to breeding for resistance should be investigated to provide more stable resistance.

Partial rust resistance would be a useful complement to race-specific resistance and has been identified in pearl millet inbreds $(8,10,13)$. The resistance expressed by inbred 'ICMP 501' is of particular interest because it has high levels of expression in segregating progeny, has significant dominance and additive genetic effects, and is controlled by relatively few genes (14). The resistance of this inbred has been called "partial" rather than "slow rusting" (13), because although 'ICMP 501' exhibits attributes of slow-rusting resistance (susceptible infection type, with smaller uredinia in seedlings and a long latent period in adult plants), it also expresses some qualitative resistance when inoculated as seedlings with certain races of the pathogen (11).

Since pearl millet hybrids with partial rust resistance have not been developed, the potential value of partial rust resistance in forage varieties is unknown. Several $\mathrm{F}_{6}$ progeny with desirable agronomic characteristics and disease resistance were selected among single-seed descent progeny of the cross Tift $383 \times$ 'ICMP 501' and the inheritance of partial resistance was examined (14). Although these selections may be useful as parental inbreds, the effectiveness of partial rust resistance in forage hybrids has yet to be evaluated. The objective of these experiments was to identify pearl millet hybrids with partial rust resistance and to evaluate the effectiveness of the resistance in sustaining digestible biomass production.

\section{MATERIALS AND METHODS}

Nine inbreds with partial resistance and desirable agronomic characteristics were selected from $\mathrm{F}_{6}$ progeny of the cross Tift $383 \times$ 'ICMP 501'. The nine inbreds and the inbred lines Tift 383 and Tift 65 were pollen parents in crosses with the cytoplasmic male sterile inbred Tift 23DA 4 . Tift 23DA 4 has no known resistance. The hybrid Tift $23 \mathrm{DA}_{4} \times$ Tift 383 differs only by cytoplasm from the rust-susceptible commercial hybrid 'Tifleaf 1' (1). The hybrid Tift $23 \mathrm{DA}_{4} \times$ Tift 65 is similar to the commercial hybrid 'Tifleaf 2' (4) and possesses the $R r_{1}$ gene for resistance (2), which is now commercially ineffective due to a race shift in the pathogen population.

Experiments were conducted to evaluate the resistance of parental inbreds and 11 hybrids and to determine the effects of rust on digestible biomass of experimental hybrids. Tests were planted at Tifton, GA, on $7 \mathrm{Au}-$ gust 1996 and 12 August 1997. Plots were planted at a rate of approximately $2.8 \mathrm{~kg}$ of seed per ha. Fertilizer (5-10-5 NPK) was applied in furrow at planting at a rate of $280 \mathrm{~kg} \mathrm{ha}^{-1}$.

Resistance evaluations of hybrids and parental inbreds. Parental inbreds and hybrids were evaluated for resistance in 1996 and 1997 in a randomized complete block design with five replications. Single-row plots were $5 \mathrm{~m}$ long, and row spacing alternated between 0.9 and $1.8 \mathrm{~m}$. Date of anthesis was defined as the date when $50 \%$ of panicles in the plot reached anthesis. Rust severities were visually estimated as percentage of foliage with uredinia or killed as a result of infection. Severities were estimated on 18 September, 26 September, 5 October, 17 October, and 25 October 1996 and on 2 October, 9 October, 16 October, 30 October, and 6 November 1997.

Because of extreme differences in maturity among the lines evaluated in this experiment, disease severities observed at any particular date were not considered to accurately reflect the relative resistance of lines. The expression of slow-rusting or partial rust resistance is often dependent upon plant maturity $(5-7,9)$. To account for differences in susceptibility due to maturity and disease pressure, two modifications were 
made to standard area under the disease progress curve (AUDPC) calculations.

The first modification was made to describe epidemic progress within a defined stage of plant growth, similar to procedures performed previously $(13,16)$, to account for differences in susceptibility due to maturity. Severities were transformed to logits $(\log [x /(1-x)]$, in which $x=$ proportion disease severity) and regressed against days from anthesis to estimate apparent infection rates. Logit values were calculated from the regression lines for 5-day intervals from 10 days before anthesis to 20 days after anthesis, and back-transformed to predicted rust severities. AUDPC for each plot was calculated as

$$
\text { AUDPC }=\Sigma\left[Y_{(i+n)}+Y_{i}\right] / 2 \times\left[X_{(i+n)}-X_{i}\right]
$$

in which $Y_{i}=$ percent predicted rust severity at time $X_{i}$, and $i=-10$ to 20 days from $50 \%$ anthesis at $n=5$-day intervals.

The second modification was made to correct for differences in disease pressure, since late-maturing lines were subjected to a greater inoculum load for a longer period of time than were early-maturing lines. Adjusted AUDPC values were calculated to correct for differences in initial rust infection due to differences in disease pressure at a more susceptible stage of plant growth. The predicted rust severity at 10 days before $50 \%$ anthesis $\left(Y_{-10}\right)$ was determined, and the adjusted AUDPC for each plot was calculated as

$$
\text { adjusted AUDPC }=\left[\text { AUDPC }-\left(Y_{-10} \times 30\right)\right](2)
$$

for the 30-day interval from 10 days before to 20 days after $50 \%$ anthesis.

Pearson's correlation coefficients between days to $50 \%$ anthesis, apparent infection rate, AUDPC (derived from equation 1), and adjusted AUDPC were calculated from plot data within years. Data for the same variables were analyzed by analyses of variance (SAS Institute, Cary, NC). Sums of squares were partitioned into year, replication within year (error a), line, and

Table 1. Analyses of variance of days to $50 \%$ anthesis and disease variables of pearl millet inbreds and hybrids evaluated in rust epidemics in 1996 and 1997

\begin{tabular}{lrcccc}
\hline & & \multicolumn{4}{c}{ Mean squares } \\
\cline { 4 - 6 } Source of variation & df & $\begin{array}{c}\text { Days to 50\% } \\
\text { anthesis }\end{array}$ & $\begin{array}{c}\text { Apparent } \\
\text { infection rate }\end{array}$ & $\begin{array}{c}\text { AUDPC }^{\mathbf{x}} \\
\left(\times \mathbf{1 0}^{\mathbf{3}}\right)\end{array}$ & $\begin{array}{c}\text { Adjusted } \\
\text { AUDPC }\left(\times \mathbf{1 0}^{\mathbf{3}}\right)\end{array}$ \\
\hline Year & 1 & $288.9^{* * z}$ & 0.00066 & $6,711.4^{* *}$ & $635.9^{*}$ \\
Replication (year), error a & 8 & 2.3 & $0.00110^{* *}$ & $149.5^{* *}$ & $69.7^{* *}$ \\
Line & 22 & $1,933.0^{* *}$ & $0.01385^{* *}$ & $2,081.1^{* *}$ & $310.2^{* *}$ \\
Year $\times$ line & 22 & $50.8^{* *}$ & $0.00195^{* *}$ & $301.3^{* *}$ & $110.2^{* *}$ \\
Error b & 175 & 5.0 & 0.00030 & 47.5 & 16.0 \\
\hline
\end{tabular}

$\mathrm{x}$ Area under the disease progress curve from -10 to 20 days from anthesis.

${ }^{y}$ Severity values used to calculate AUDPC were adjusted for rust severities at 10 days before anthesis.

$\mathrm{z} *$ and $* *$ indicate significance at $P=0.05$ and 0.01 , respectively. year $\times$ line interaction. Means were differentiated by Fisher's least significant difference test.

Hybrid yield performance. Hybrid yield tests were planted in 1996 and 1997 in a split-plot design with five replications to assess digestible biomass production. Main plots were 5-m long, two-row plots of each hybrid with $1.8-\mathrm{m}$ spacing between rows. Subplot treatments were nontreated or chlorothalonil fungicide application (Bravo 720 [chlorothalonil], $3.6 \mathrm{ml} /$ liter) applied to runoff with a hand-held sprayer on 30 August, 6 September, 13 September, 23 September, 30 September, and 4 October 1996, and on 10 September, 18 September, 25 September, 3 October, 9 October, 21 October, and 29 October 1997. Rust severities were estimated on the same dates as the experiment above. Because of the similarities in maturity among the hybrids, standard AUDPCs were calculated with equation 1 with actual severity values $Y_{i}$ observed at times $X_{i}$, in which $n=$ days between evaluation dates for the duration of the epidemic.

Anthesis date, plant height, and lodging (visual estimate of percent lodged culms) prior to harvest was determined in 1997. Plots were harvested with a forage chopper on 25 October 1996 and 6 November 1997 to measure green yield. In 1996 and 1997, samples (approximately $300 \mathrm{~g}$ each) from plots were weighed at harvest and again after drying at $60^{\circ} \mathrm{C}$ for $48 \mathrm{~h}$ in a forced-air oven to determine dry matter proportion (DM). Dry matter yield (DMY) was calculated as the product of green yield and DM. In vitro dry matter digestibility (IVDMD) of samples was determined by a two-stage incubation as described previ-

Table 2. Maturity, apparent infection rate, and adjusted area under the disease progress curve (AUDPC) of pearl millet inbreds and hybrids evaluated in

\begin{tabular}{|c|c|c|c|c|c|c|c|c|c|}
\hline \multirow[b]{2}{*}{ Inbred or hybrid } & \multicolumn{3}{|c|}{ Days to $50 \%$ anthesis } & \multicolumn{3}{|c|}{ Apparent infection rate } & \multicolumn{3}{|c|}{ Adjusted AUDPCy } \\
\hline & 1996 & 1997 & Mean & 1996 & 1997 & Mean & 1996 & 1997 & Mean \\
\hline Tift $23 \mathrm{DA}_{4}$ & 60 & 62 & 61 & 0.165 & 0.199 & 0.180 & 1,321 & 1,312 & 1,317 \\
\hline 1571 & 85 & 74 & 79 & 0.086 & 0.095 & 0.091 & 745 & 963 & 854 \\
\hline 1572 & 62 & 64 & 63 & 0.163 & 0.168 & 0.166 & 936 & 732 & 834 \\
\hline 1573 & 94 & 93 & 94 & 0.100 & 0.062 & 0.081 & 942 & 560 & 751 \\
\hline 1574 & 82 & 76 & 79 & 0.103 & 0.103 & 0.103 & 992 & 851 & 921 \\
\hline 1575 & 103 & 102 & 103 & 0.101 & 0.047 & 0.074 & 619 & 423 & 521 \\
\hline 1576 & 84 & 71 & 77 & 0.068 & 0.098 & 0.083 & 691 & 936 & 813 \\
\hline 1577 & 77 & 77 & 77 & 0.092 & 0.080 & 0.086 & 846 & 777 & 812 \\
\hline 1578 & 74 & 74 & 74 & 0.125 & 0.076 & 0.101 & 1,009 & 486 & 747 \\
\hline 1579 & 75 & 76 & 75 & 0.104 & 0.050 & 0.077 & 852 & 321 & 586 \\
\hline Tift 65 & 72 & 66 & 69 & 0.121 & 0.113 & 0.117 & 1112 & 927 & 1,019 \\
\hline Tift 383 & 80 & 67 & 73 & 0.085 & 0.124 & 0.104 & 848 & 1,166 & 1,007 \\
\hline $23 \mathrm{DA}_{4} \times 1571$ & 57 & 55 & 56 & 0.156 & 0.168 & 0.161 & 1,053 & 826 & 940 \\
\hline $23 \mathrm{DA}_{4} \times 1572$ & 51 & 53 & 52 & 0.161 & 0.167 & 0.164 & 656 & 706 & 681 \\
\hline $23 \mathrm{DA}_{4} \times 1573$ & 59 & 57 & 58 & 0.137 & 0.154 & 0.145 & 745 & 627 & 686 \\
\hline $23 \mathrm{DA}_{4} \times 1574$ & 57 & 56 & 56 & 0.143 & 0.170 & 0.157 & 773 & 682 & 728 \\
\hline $23 \mathrm{DA}_{4} \times 1575$ & 58 & 57 & 57 & 0.122 & 0.154 & 0.138 & 573 & 636 & 605 \\
\hline $23 \mathrm{DA}_{4} \times 1576$ & 56 & 56 & 56 & 0.132 & 0.171 & 0.151 & 909 & 931 & 920 \\
\hline $23 \mathrm{DA}_{4} \times 1577$ & 54 & 53 & 53 & 0.179 & 0.185 & 0.182 & 1,073 & 918 & 995 \\
\hline $23 \mathrm{DA}_{4} \times 1578$ & 55 & 54 & 55 & 0.147 & 0.154 & 0.151 & 741 & 600 & 671 \\
\hline $23 \mathrm{DA}_{4} \times 1579$ & 53 & 54 & 54 & 0.155 & 0.165 & 0.160 & 778 & 698 & 738 \\
\hline $23 \mathrm{DA}_{4} \times$ Tift 65 & 55 & 54 & 54 & 0.164 & 0.180 & 0.172 & 1,000 & 922 & 961 \\
\hline $23 \mathrm{DA}_{4} \times$ Tift 383 & 56 & 55 & 55 & 0.157 & 0.165 & 0.161 & 1,108 & 911 & 1,010 \\
\hline $\mathrm{LSD}^{\mathrm{z}}$ & 3 & 3 & 1 & 0.019 & 0.024 & 0.020 & 150 & 169 & 171 \\
\hline
\end{tabular}
rust epidemics in 1996 and 1997

y Severity values used to calculate AUDPC were adjusted for rust severities at 10 days before anthesis.

${ }^{\mathrm{z}} \mathrm{LSD}=$ least significant difference at $P=0.05$. 
ously (15). DDMY was calculated as the product of DMY and IVDMD.

Data from disease, yield, and agronomic evaluations were analyzed by analyses of variance. Sums of squares for days to anthesis, height, and lodging from 1997 were partitioned into replication, hybrid, and fungicide treatment main effects with appropriate two-factor interactions. Sums of squares for final rust severity, AUDPC, DMY, IVDMD, and DDMY from 1996 and 1997 were partitioned into year, hybrid, and fungicide treatment main effects, and all two- and three-factor interactions. Hybrid means within year $\times$ fungicide treatment were differentiated by Fisher's least significant difference test.

DDMY data for nontreated plots in 1996 and 1997 were analyzed by analysis of variance, with sums of squares partitioned into year, replication within year (error a), hybrid, and year $\times$ hybrid interaction to determine if nontreated plots yielded similarly between years. To compare hybrids with partial resistance with those that were susceptible, hybrids were differentiated according to their level of disease resistance by Ward's cluster analysis (SAS Institute). Cluster analysis was performed using standardized means by year for apparent infection rate and adjusted AUDPC from the resistance evaluations and for final severity and AUDPC for treated and nontreated plots from the yield tests (12 disease-related variables total). Year $\times$ treatment means of DDMY of hybrids were regressed against final disease severity to determine the digestible biomass response to rust infection.

Stability analyses (3) were performed to compare the responses of partially resistant and susceptible hybrids. Year $\times$ treatment means of final rust severity, AUDPC, DM, DMY, IVDMD, and DDMY for all hybrids within the partially resistant and susceptible clusters defined by cluster analysis were determined and regressed on the average performance of all hybrids for each year $x$ treatment combination. Deviations of calculated slopes from 1, which indicates average stability, and differentiation of slopes between clusters were determined by $t$ tests.

\section{RESULTS AND DISCUSSION}

Resistance evaluations of hybrids and parental inbreds. Year was a significant source of variation for days to $50 \%$ anthesis, AUDPC, and adjusted AUDPC (Table $1)$. Line and year $\times$ line interactions were significant for days to $50 \%$ anthesis, apparent infection rate, AUDPC, and adjusted AUDPC.

Days to $50 \%$ anthesis ranged from 51 to 59 days for hybrids and from 60 to 103 days for inbreds in 1996 and 1997 (Table 2). The differences in maturity resulted in differences in disease pressure (primarily due to inoculum levels and duration of exposure to inoculum) between the early- and late-maturing lines, complicating comparisons of disease resistance.
Regressions of logit severity versus time were best fit by linear models. Coefficients of determination $\left(r^{2}\right)$ were predominantly greater than 0.90 . Probability of fit to a linear model was $P<0.05$ for 207 plots, $P=$ 0.05 to 0.08 for 19 plots, and $P=0.10$ to 0.12 for 3 plots. For those plots in which the linear model did not describe epidemic progress, data from only one plot better fit a quadratic $(P=0.04)$ than a linear $(P=$ $0.06)$ model. The apparent infection rate, estimated as the slope of the logit regression line, was considered to be an acceptable parameter for comparing epidemic development among lines.

Because rust had already increased to a significant level on the late-maturing hybrids and inbreds prior to anthesis, AUDPC estimates were confounded. In 1996, average estimated severities at 10 days prior to anthesis ranged from 1 to $59 \%$ for entries $23 \mathrm{DA}_{4} \times 1572$ and 1575 , respectively. In 1997, average estimated severities at 10 days prior to anthesis ranged from 1 to $41 \%$ for entries $23 \mathrm{DA}_{4} \times 1574$ and 1577 , respectively. The potential problems in comparing AUDPCs of early- and late-maturing entries are evident. For example, when comparing hypothetical genotypes that do not differ in apparent infection rate, but differ in maturity such that a difference of $10 \%$ in disease severity occurs at the initial rating, the $10 \%$ difference would result in a 300 unit difference in AUDPC values calculated over a 30-day interval. Subtracting the initial severity from subsequent severity estimates

Table 3. Pearson's correlation coefficients among apparent infection rate, area under the disease progress curve (AUDPC), and adjusted AUDPC of pearl millet inbreds and hybrids evaluated in rust epidemics in 1996 and 1997

\begin{tabular}{lcccc}
\hline Variable & Year & $\begin{array}{c}\text { Apparent } \\
\text { infection rate }\end{array}$ & AUDPC $^{\mathbf{x}}$ & $\begin{array}{c}\text { Adjusted } \\
\text { AUDPC }^{\mathbf{y}}\end{array}$ \\
\hline Days to 50\% anthesis & 1996 & $-0.758^{* * \mathrm{z}}$ & $0.823^{* *}$ & -0.148 \\
& 1997 & $-0.828^{* *}$ & $0.325^{* *}$ & $-0.308^{* *}$ \\
Apparent infection rate & 1996 & & $-0.504^{* *}$ & $0.438^{* *}$ \\
& 1997 & & $-0.191^{*}$ & $0.520^{* *}$ \\
AUDPC & 1996 & & & $0.202^{*}$ \\
& 1997 & & & $0.646^{* *}$ \\
\hline
\end{tabular}

${ }^{x}$ Area under the disease progress curve from -10 to 20 days from anthesis.

${ }^{y}$ Severity values used to calculate AUDPC were adjusted for rust severities at 10 days before anthesis.

$\mathrm{z} *$ and $* *$ indicate significance at $P=0.05$ and 0.01 , respectively.

Table 4. Analyses of variance of agronomic characteristics of hybrids with partial rust resistance evaluated in 1997

\begin{tabular}{lrccc}
\hline & & \multicolumn{3}{c}{ Mean squares } \\
\cline { 4 - 5 } Source of variation & df & Days to anthesis & Height & Lodging \\
\hline Replication & 4 & 2.03 & 0.22 & $583^{* y}$ \\
Hybrid $(\mathrm{H})$ & 10 & $17.74^{* *}$ & $1.42^{* *}$ & $1,236^{* *}$ \\
Replication $\times$ hybrid (error a) & 40 & $1.66^{* *}$ & 0.27 & 179 \\
Fungicide treatment $(\mathrm{F})^{\mathrm{z}}$ & 1 & 0.10 & $5.47^{* *}$ & $11,626^{* *}$ \\
$\mathrm{H} \times \mathrm{F}$ & 10 & 0.53 & 0.16 & $1,237^{* *}$ \\
Error $\mathrm{b}$ & 44 & 0.67 & 0.25 & 217 \\
\hline
\end{tabular}

y $*$ and $* *$ indicate significance at $P=0.05$ and 0.01 , respectively.

${ }^{\mathrm{z}}$ Chlorothalonil fungicide-treated or nontreated.

Table 5. Means for agronomic assessments of pearl millet hybrids with partial rust resistance evaluated in 1997

\begin{tabular}{|c|c|c|c|c|}
\hline \multirow[b]{2}{*}{ Hybrid } & \multirow[b]{2}{*}{ Days to anthesis } & \multicolumn{2}{|c|}{ Height (cm) } & \multirow[b]{2}{*}{$\operatorname{Lodging}^{x}(\%)$} \\
\hline & & Nontreated & Fungicide treated & \\
\hline $23 \mathrm{DA}_{4} \times 1571$ & $56.7 \mathrm{bc}^{\mathrm{y}}$ & $149 \mathrm{bc}$ & $157 \mathrm{abc}$ & $39.2 \mathrm{ab}$ \\
\hline $23 \mathrm{DA}_{4} \times 1572$ & $53.4 \mathrm{~g}$ & $149 \mathrm{bc}$ & 152 cde & $0.8 \mathrm{~d}$ \\
\hline $23 \mathrm{DA}_{4} \times 1573$ & $57.9 \mathrm{a}$ & $155 \mathrm{ab}$ & $158 \mathrm{abc}$ & $0.1 \mathrm{~d}$ \\
\hline $23 \mathrm{DA}_{4} \times 1574$ & $56.1 \mathrm{bcd}$ & $148 \mathrm{c}$ & $149 \mathrm{e}$ & $0.8 \mathrm{~d}$ \\
\hline $23 \mathrm{DA}_{4} \times 1575$ & $58.0 \mathrm{a}$ & $158 \mathrm{abc}$ & $161 \mathrm{a}$ & $8.7 \mathrm{~cd}$ \\
\hline $23 \mathrm{DA}_{4} \times 1576$ & $56.8 \mathrm{~b}$ & $156 \mathrm{a}$ & $160 \mathrm{ab}$ & $47.6 \mathrm{ab}$ \\
\hline $23 \mathrm{DA}_{4} \times 1577$ & $55.5 \mathrm{de}$ & $148 \mathrm{c}$ & 154 bcde & $44.7 \mathrm{ab}$ \\
\hline $23 \mathrm{DA}_{4} \times 1578$ & $54.8 \mathrm{ef}$ & $147 \mathrm{c}$ & $148 \mathrm{e}$ & $0.2 \mathrm{~d}$ \\
\hline $23 \mathrm{DA}_{4} \times 1579$ & $54.5 \mathrm{f}$ & $147 \mathrm{c}$ & $150 \mathrm{de}$ & $3.0 \mathrm{~cd}$ \\
\hline $23 \mathrm{DA}_{4} \times$ Tift 65 & 55.8 cde & $150 \mathrm{abc}$ & 156 abcd & $54.9 \mathrm{a}$ \\
\hline $23 \mathrm{DA}_{4} \times$ Tift 383 & $56.0 \mathrm{bcd}$ & $153 \mathrm{abc}$ & $159 \mathrm{ab}$ & $26.7 \mathrm{bc}$ \\
\hline $\mathrm{LSD}^{\mathrm{z}}$ & 0.8 & 6 & 6 & 24.2 \\
\hline
\end{tabular}

${ }^{x}$ Lodging in nontreated plots only.

${ }^{y}$ Means within a column followed by the same letter do not differ $(P=0.05)$.

${ }^{\mathrm{z}} \mathrm{LSD}=$ least significant difference at $P=0.05$. 
would provide information on disease progress adjusted for initial infection levels.

Days to $50 \%$ anthesis was positively correlated with AUDPC (Table 3), which is consistent with the observation that disease pressure was greater on late-maturing lines. Apparent infection rate was negatively correlated with AUDPC in both years. It would be expected that low apparent infection rates should result in low AUDPCs, indicating that an adjustment for initial infection was necessary. Apparent infection rates were positively correlated with adjusted AUDPCs in both years, supporting the premise that adjusting for initial infection is a valid procedure to assess resistance more accurately.

In comparisons of apparent infection rates, Tift $23 \mathrm{DA}_{4}$ and $23 \mathrm{DA}_{4} \times 1577$ had the largest values and, thus, were the most susceptible lines (Table 2). Apparent infection rates of 1572 and its hybrid $23 \mathrm{DA}_{4} \times 1572$

Table 6. Analyses of variance of disease development and yield components of pearl millet hybrids with partial rust resistance evaluated in 1996 and 1997

\begin{tabular}{|c|c|c|c|c|c|c|}
\hline \multirow[b]{2}{*}{ Source of variation } & \multirow[b]{2}{*}{ df } & \multicolumn{5}{|c|}{ Mean squares } \\
\hline & & $\begin{array}{c}\text { Final rust } \\
\text { severity }\end{array}$ & $\begin{array}{c}\operatorname{AUDPC}_{\left(\times 10^{3}\right)}^{\mathbf{v}} \\
\end{array}$ & $\begin{array}{l}\text { DMYw }^{\left(\times 10^{4}\right)}\end{array}$ & $\begin{array}{c}\text { IVDMD }_{\left(\times 10^{-4}\right)} \\
\end{array}$ & $\begin{array}{c}\text { DDMY }^{y} \\
\left(\times 10^{4}\right)\end{array}$ \\
\hline Year (Y) & 1 & $2,082 * * \mathrm{z}$ & $400^{*}$ & $16,804 * *$ & 193 & $3,312 * *$ \\
\hline Replication (year) & 8 & 82 & $52 * *$ & 159 & $83 * *$ & 76 \\
\hline Hybrid $(\mathrm{H})$ & 10 & $901 * *$ & $865^{* *}$ & $672 * *$ & $103 * *$ & $372 * *$ \\
\hline Year $\times$ hybrid & 10 & $151^{* *}$ & 28 & 49 & $28 *$ & 27 \\
\hline Pooled error a & 80 & 39 & 19 & $182 *$ & 14 & 47 \\
\hline Fungicide treatment $(\mathrm{F})$ & 1 & $253,929 * *$ & $84,232 * *$ & $38,017 * *$ & $3,557 * *$ & $18,519 * *$ \\
\hline $\mathrm{Y} \times \mathrm{F}$ & 1 & $11,611^{* *}$ & $2,923^{* *}$ & $4,390^{* * *}$ & $667 * *$ & $2,788 * *$ \\
\hline $\mathrm{H} \times \mathrm{F}$ & 10 & $227 * *$ & $346^{* *}$ & 181 & 32 & 62 \\
\hline $\mathrm{Y} \times \mathrm{H} \times \mathrm{F}$ & 10 & 78 & 23 & 126 & 11 & 48 \\
\hline Error b & 88 & 43 & 14 & 116 & 28 & 38 \\
\hline
\end{tabular}

${ }^{\mathrm{v}}$ Area under the disease progress curve.

${ }^{w}$ Dry matter yield.

${ }^{\mathrm{x}}$ In vitro dry matter digestibility.

${ }^{y}$ Digestible dry matter yield.

$\mathrm{z} *$ and $* *$ indicate significance at $P=0.05$ and 0.01 , respectively. did not differ. For all other comparisons of inbreds and their hybrids, inbreds had lower apparent infection rates than those of their hybrids. In 1996, only hybrids produced with $1573,1574,1575$, and 1576 had apparent infection rates less than that of Tift 23DA 4 . In 1997, hybrids produced with $1571,1572,1573,1574,1575,1576$, 1578, 1579, and Tift 383 had apparent infection rates less than that of Tift $23 \mathrm{DA}_{4}$. Over years, hybrids produced with 1573 , $1574,1575,1576$, and 1579 had apparent infection rates less than that of Tift $23 \mathrm{DA}_{4}$.

In comparison of adjusted AUDPCs, Tift $23 \mathrm{DA}_{4}$ had the largest value and, thus, was the most susceptible line (Table 2). In 1996, inbreds 1571, 1576, 1577, and Tift 383 had smaller adjusted AUDPCs than those of their hybrids. Inbreds 1572, 1573, 1574, and 1578 had greater adjusted AUDPCs than those of their hybrids. Adjusted AUDPCs of the other inbreds did not differ from those of their hybrids. In 1997, inbreds 1575 and 1579 had smaller adjusted AUDPCs than those of their hybrids. Adjusted AUDPC of Tift 383 was greater than that of its hybrid. Adjusted AUDPCs of the other inbreds did not differ from those of their hybrids. Over years, adjusted AUDPC of inbred 1577 was less than that of its hybrid and that of 1574 was greater than that of its hybrid. Adjusted AUDPCs of the other inbreds did not differ from those of their hybrids. Within

Table 7. Means for disease reactions and agronomic assessments of pearl millet hybrids with partial rust resistance evaluated in 1996 and 1997

\begin{tabular}{|c|c|c|c|c|c|c|c|c|c|c|}
\hline \multirow[b]{2}{*}{$\begin{array}{l}\text { Year and } \\
\text { hybrid }\end{array}$} & \multicolumn{2}{|c|}{ Final severity $(\%)$} & \multicolumn{2}{|c|}{ AUDPCs } & \multicolumn{2}{|c|}{ DMY $(\mathrm{kg} / \mathrm{ha})^{\mathrm{t}}$} & \multicolumn{2}{|c|}{ IVDMD $^{u}$} & \multicolumn{2}{|c|}{ DDMY (kg/ha) ${ }^{\mathbf{v}}$} \\
\hline & Nontreated & $\begin{array}{c}\text { Fungicide } \\
\text { treated }\end{array}$ & Nontreated & $\begin{array}{c}\text { Fungicide } \\
\text { treated }\end{array}$ & Nontreated & $\begin{array}{c}\text { Fungicide } \\
\text { treated }\end{array}$ & Nontreated & $\begin{array}{c}\text { Fungicide } \\
\text { treated }\end{array}$ & Nontreated & $\begin{array}{c}\text { Fungicide } \\
\text { treated }\end{array}$ \\
\hline \multicolumn{11}{|l|}{1996} \\
\hline $23 \mathrm{DA}_{4} \times 1571$ & $90 a^{x}$ & $29 \mathrm{bcd}$ & $1,658 \mathrm{~b}$ & $584 \mathrm{ab}$ & $5,112 \mathrm{~b}$ & $7,738 a b c$ & $0.44 \mathrm{c}$ & $0.49 \mathrm{bc}$ & $2,261 \mathrm{c}$ & $3,788 a b c$ \\
\hline $23 \mathrm{DA}_{4} \times 1572$ & $85 \mathrm{ab}$ & 26 bcde & $1,604 \mathrm{~b}$ & $390 \mathrm{~cd}$ & $5,220 \mathrm{~b}$ & 6,922 abcd & $0.47 \mathrm{abc}$ & $0.48 \mathrm{bc}$ & $2,468 \mathrm{bc}$ & $3,290 \mathrm{~cd}$ \\
\hline $23 \mathrm{DA}_{4} \times 1573$ & $69 c$ & $21 \mathrm{de}$ & $1,001 \mathrm{~d}$ & $283 d$ & $6,373 \mathrm{a}$ & $7,262 \mathrm{abc}$ & $0.51 \mathrm{a}$ & $0.54 \mathrm{a}$ & $3,248 \mathrm{a}$ & $3,910 a b c$ \\
\hline $23 \mathrm{DA}_{4} \times 1574$ & $73 \mathrm{c}$ & $21 \mathrm{de}$ & $1,169 \mathrm{~cd}$ & $343 \mathrm{~d}$ & $5,125 \mathrm{~b}$ & $7,127 \mathrm{abcd}$ & $0.47 \mathrm{abc}$ & $0.51 \mathrm{abc}$ & $2,411 \mathrm{~cd}$ & $3,657 \mathrm{~cd}$ \\
\hline $23 \mathrm{DA}_{4} \times 1575$ & $58 \mathrm{~d}$ & $18 \mathrm{e}$ & $951 \mathrm{~d}$ & $242 \mathrm{~d}$ & $6,375 \mathrm{a}$ & $8,291 \mathrm{a}$ & $0.50 \mathrm{ab}$ & $0.53 \mathrm{ab}$ & $3,233 \mathrm{a}$ & $4,424 \mathrm{a}$ \\
\hline $23 \mathrm{DA}_{4} \times 1576$ & $87 \mathrm{ab}$ & $33 \mathrm{ab}$ & $1,698 \mathrm{ab}$ & $497 \mathrm{bc}$ & $5,157 \mathrm{~b}$ & $6,680 \mathrm{bcd}$ & $0.43 \mathrm{c}$ & $0.48 \mathrm{c}$ & $2,218 \mathrm{c}$ & $3,220 \mathrm{~cd}$ \\
\hline $23 \mathrm{DA}_{4} \times 1577$ & $93 \mathrm{a}$ & $30 \mathrm{bcd}$ & $1,929 \mathrm{a}$ & $516 b c$ & $5,265 \mathrm{~b}$ & $6,469 \mathrm{~cd}$ & $0.42 \mathrm{c}$ & $0.51 \mathrm{abc}$ & $2,245 \mathrm{c}$ & $3,306 \mathrm{~cd}$ \\
\hline $23 \mathrm{DA}_{4} \times 1578$ & $74 \mathrm{c}$ & $23 \mathrm{cde}$ & $1,084 \mathrm{~d}$ & $339 \mathrm{~d}$ & $5,080 \mathrm{~b}$ & $8,096 \mathrm{ab}$ & $0.47 \mathrm{abc}$ & $0.52 \mathrm{abc}$ & $2,374 \mathrm{bc}$ & $4,146 \mathrm{ab}$ \\
\hline $23 \mathrm{DA}_{4} \times 1579$ & $78 \mathrm{bc}$ & 26 bcde & $1,324 \mathrm{c}$ & $376 \mathrm{~cd}$ & $6,267 \mathrm{a}$ & $7,638 \mathrm{abc}$ & $0.46 \mathrm{abc}$ & $0.51 \mathrm{abc}$ & $2,899 \mathrm{ab}$ & $3,951 \mathrm{abc}$ \\
\hline $23 \mathrm{DA}_{4} \times$ Tift 65 & $92 \mathrm{a}$ & $32 \mathrm{bc}$ & $1,759 \mathrm{ab}$ & $543 \mathrm{~b}$ & $4,713 \mathrm{~b}$ & $5,812 \mathrm{~d}$ & $0.45 \mathrm{bc}$ & $0.51 \mathrm{abc}$ & $2,091 \mathrm{c}$ & $2,985 \mathrm{~d}$ \\
\hline $23 \mathrm{DA}_{4}^{4} \times \operatorname{Tift} 383$ & $90 \mathrm{a}$ & $42 \mathrm{a}$ & $1,740 \mathrm{ab}$ & $727 \mathrm{a}$ & $5,061 \mathrm{~b}$ & $6,806 \mathrm{bcd}$ & $0.43 \mathrm{c}$ & $0.49 \mathrm{bc}$ & $2,180 \mathrm{c}$ & $3,306 \mathrm{~cd}$ \\
\hline LSD $^{y}$ & 11 & 9 & 232 & 152 & 967 & 1,419 & 0.06 & 0.05 & 550 & 742 \\
\hline \multicolumn{11}{|l|}{1997} \\
\hline $23 \mathrm{DA}_{4} \times 1571$ & $95 \mathrm{ab}$ & $7 \mathrm{~cd}$ & $1,815 \mathrm{bc}$ & $149 \mathrm{ab}$ & 5,688 cde & 10,319 & $0.41 \mathrm{~cd}$ & $0.53 \mathrm{ab}$ & 2,333 cde & $5,452 a b c$ \\
\hline $23 \mathrm{DA}_{4} \times 1572$ & $92 \mathrm{bc}$ & $5 \mathrm{ef}$ & $1,831 \mathrm{bc}$ & $108 \mathrm{~cd}$ & $6,034 \mathrm{cde}$ & 9,758 & $0.41 \mathrm{~cd}$ & $0.50 \mathrm{bc}$ & $2,467 \mathrm{~cd}$ & $4,861 \mathrm{bcd}$ \\
\hline $23 \mathrm{DA}_{4} \times 1573$ & $66 \mathrm{f}$ & $5 \mathrm{f}$ & $1,045 \mathrm{f}$ & $90 \mathrm{de}$ & $7,117 \mathrm{ab}$ & 10,142 & $0.41 \mathrm{~cd}$ & $0.54 \mathrm{ab}$ & $2,878 \mathrm{bc}$ & $5,449 a b c$ \\
\hline $23 \mathrm{DA}_{4} \times 1574$ & $85 \mathrm{de}$ & $6 \mathrm{de}$ & $1,351 \mathrm{de}$ & $104 \mathrm{~cd}$ & $6,874 a b c$ & 8,732 & $0.41 \mathrm{~cd}$ & $0.48 \mathrm{c}$ & $2,792 \mathrm{bc}$ & $4,124 \mathrm{~d}$ \\
\hline $23 \mathrm{DA}_{4} \times 1575$ & $86 \mathrm{~cd}$ & $5 \mathrm{f}$ & 1,209 ef & $73 \mathrm{e}$ & $7,432 \mathrm{a}$ & 10,726 & $0.48 \mathrm{a}$ & $0.56 \mathrm{a}$ & $3,531 \mathrm{a}$ & $6,007 \mathrm{a}$ \\
\hline $23 \mathrm{DA}_{4} \times 1576$ & $97 \mathrm{ab}$ & 8 bcd & $1,700 \mathrm{c}$ & $157 \mathrm{ab}$ & $6,739 a b c$ & 9,421 & 0.39 cdef & $0.53 \mathrm{abc}$ & $2,623 \mathrm{~cd}$ & $4,969 \mathrm{abcd}$ \\
\hline $23 \mathrm{DA}_{4} \times 1577$ & $98 \mathrm{a}$ & $8 b c$ & $2,023 \mathrm{a}$ & $135 \mathrm{bc}$ & $5,179 \mathrm{de}$ & 8,978 & $0.35 \mathrm{ef}$ & $0.53 \mathrm{abc}$ & $1,834 \mathrm{ef}$ & $4,760 \mathrm{~cd}$ \\
\hline $23 \mathrm{DA}_{4} \times 1578$ & $80 \mathrm{e}$ & $5 \mathrm{f}$ & $1,343 \mathrm{de}$ & $88 \mathrm{de}$ & 6,458 abcd & 10,678 & $0.44 \mathrm{abc}$ & $0.55 \mathrm{a}$ & $2,855 \mathrm{bc}$ & $5,914 \mathrm{ab}$ \\
\hline $23 \mathrm{DA}_{4} \times 1579$ & $89 \mathrm{~cd}$ & $6 \mathrm{de}$ & $1,421 \mathrm{~d}$ & $111 \mathrm{~cd}$ & $7,058 \mathrm{ab}$ & 10,002 & $0.46 \mathrm{ab}$ & $0.52 \mathrm{abc}$ & $3,244 \mathrm{ab}$ & $5,173 \mathrm{abcd}$ \\
\hline $23 \mathrm{DA}_{4} \times$ Tift 65 & $97 \mathrm{ab}$ & $9 \mathrm{a}$ & $1,831 \mathrm{bc}$ & $178 \mathrm{a}$ & $5,017 \mathrm{e}$ & 10,028 & $0.35 \mathrm{f}$ & $0.51 \mathrm{abc}$ & $1,720 \mathrm{f}$ & $5,135 \mathrm{abcd}$ \\
\hline $23 \mathrm{DA}_{4} \times$ Tift 383 & $97 \mathrm{ab}$ & $9 \mathrm{ab}$ & $1,945 \mathrm{ab}$ & $173 \mathrm{a}$ & $5,550 \mathrm{cde}$ & 9,111 & $0.37 \mathrm{def}$ & $0.50 \mathrm{bc}$ & 2,054 ef & $4,508 \mathrm{~cd}$ \\
\hline LSD & 6 & 1 & 169 & 31 & 1,358 & $\mathrm{NS}^{\mathrm{z}}$ & 0.05 & 0.05 & 594 & 1,133 \\
\hline
\end{tabular}

${ }^{\mathrm{s}}$ Area under the disease progress curve.

${ }^{\mathrm{t}}$ Dry matter yield.

u In vitro dry matter digestibility.

${ }^{\mathrm{v}}$ Digestible dry matter yield.

${ }^{\mathrm{w}}$ Foliar chlorothalonil applications.

${ }^{x}$ Means within a column within years followed by the same letter do not differ $(P=0.05)$.

y LSD = least significant difference at $P=0.05$.

${ }^{\mathrm{z}}$ NS indicates nonsignificant. 
and over years, adjusted AUDPCs of all hybrids were less than that of Tift 23DA 4 .

Inbred resistance was not a good indicator of hybrid resistance. Within years, correlations between apparent infection rate of inbreds and their corresponding hybrids were not significant. Correlations between adjusted AUDPC values of inbreds and hybrids were significant $(r=0.63, P=0.04$ ) only in 1997. Although inbreds with potentially useful partial resistance can be selected, evaluation of resistance in hybrid combination is necessary to identify hybrids with effective partial resistance.

Hybrid yield performance. In 1997, hybrid was a significant source of variation in analyses of variance of days to anthesis, height, and lodging, and fungicide treatment was significant for height and lodging (Table 4). Days to anthesis ranged from 53 to 58 days in 1997 (Table 5), similar to the range for the hybrids in the resistance evaluations. Mean height of plants in fungicide-treated plots were $4 \mathrm{~cm}$ greater than that of plants in nontreated plots. Over treatments, the range of heights differed by $13 \mathrm{~cm}$. Although statistically significant differences existed among hybrids, the differences were not considered to be of a magnitude that would preclude direct resistance and yield comparisons of the hybrids. No lodging occurred in 1996 or in the fungicide-treated plots in 1997. Nontreated hybrids developed from crosses of Tift $23 \mathrm{DA}_{4}$ with 1571 , 1576, 1577, Tift 65, and Tift 383 were most prone to lodging in nontreated plots in 1997.

Year was a significant source of variation for all disease and digestible biomassrelated variables except IVDMD (Table 6). Hybrid, fungicide treatment, and year $\times$ fungicide interaction were consistently significant sources of variation. Better disease control was obtained in 1997 (Table 7), which resulted in the significant year $\times$ fungicide treatment interactions.

When considering both final severity and AUDPC over years and treatments, inbreds $1573,1574,1575$, and 1578 produced some of the most resistant hybrids, and 1571, 1576, 1577, Tift 65, and Tift 383 produced the most susceptible hybrids (Table 7). Over years and treatments, inbreds 1575 and 1579 produced hybrids with consistently high DMY, IVDMD, and DDMY, while 1577 and Tift 383 produced hybrids with low DMY, IVDMD, and DDMY.

In the analysis of variance of DDMY of nontreated plots, year and year $\times$ hybrid mean squares were not significant $(P>$ 0.43 ), which indicated that hybrid yields could be compared over years. Ward's cluster analysis of disease-related variables separated the hybrids into two clusters. Cluster 1 consisted of susceptible hybrids made from inbreds 1571, 1576, 1577, Tift 65 , and Tift 383 . The hybrids classified as susceptible were most prone to lodging in 1997 (Table 5), a phenomenon previously observed with severe rust infection of susceptible grain hybrids (17). Cluster 2 con- sisted of the partially resistant hybrids made from inbreds 1572, 1573, 1574, 1575, 1578, and 1579. The relationship between DDMY of each year $\times$ treatment mean for each hybrid when regressed on final rust severity was curvilinear (Fig. 1). The regression equation for the response curve was $Y=$ $7,043-1,033 \ln (X)\left(r^{2}=0.88\right)$, in which $Y=$ DDMY and $X=$ final rust severity. Hybrids classified as having partial resistance tended to have greater DDMY than those of the susceptible hybrids, as would be expected from previously determined yield response relationships (15).

The susceptible cluster of hybrids had greater slopes than those of the partial resistance cluster of hybrids in the stability analyses (Table 8). Slopes from regressions of final rust severity and DMY for each cluster were not significantly different from
1 , but in pairwise $t$ tests, slopes of the regression lines of each cluster differed. The lower slopes of the partial resistance cluster indicated that the resistance- and yield-associated variables for this group of hybrids were more stable over the year $x$ treatment environments than were those of the susceptible cluster of hybrids.

Although the effectiveness of the resistance of these hybrids is likely to be underestimated in these experiments by their proximity to susceptible hybrids due to interplot interference, the resistance observed would provide only limited biomass protection in severe rust epidemics. These inbreds express the minimum levels of partial resistance required during parental selection. Certain inbreds identified in these experiments will be most useful as parents in combination with other inbreds that express

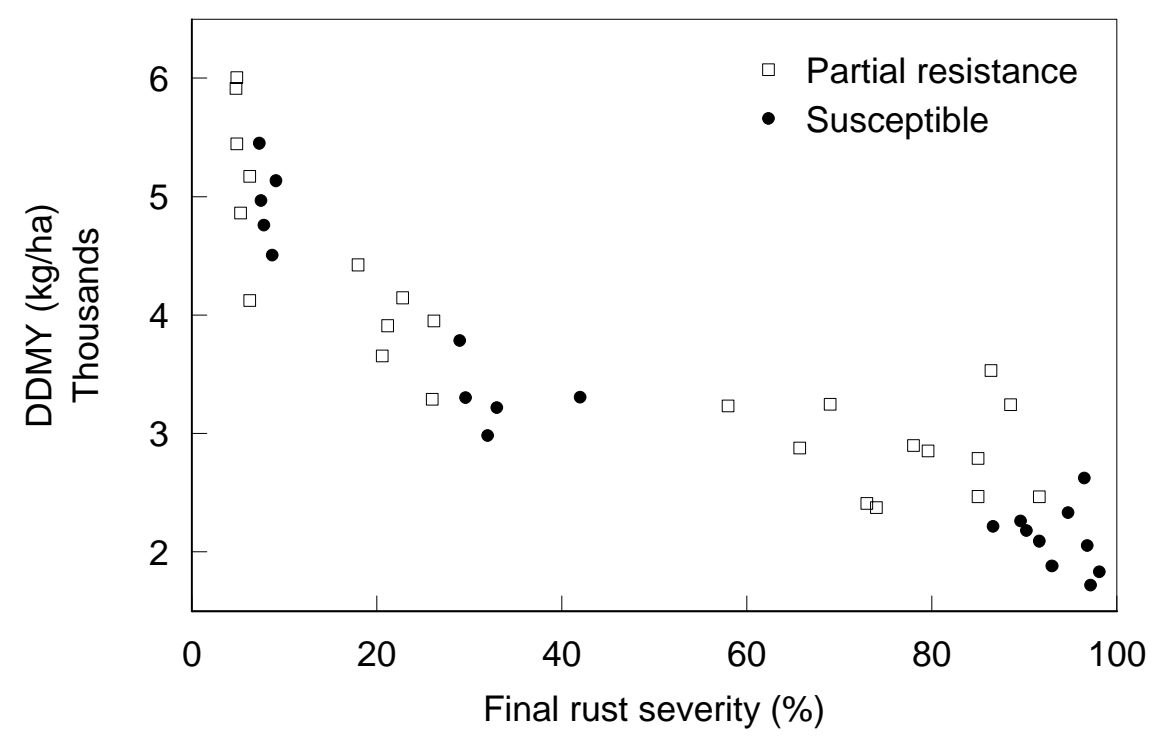

Fig. 1. Relationship between digestible dry matter yield and final rust severity in nontreated and fungicide-treated plots of pearl millet hybrids with different levels of partial resistance to Puccinia substriata var. indica. Clusters of partially resistant and susceptible hybrids were determined by cluster analysis of disease data from 1996 and 1997. Data points are hybrid means within year $\times$ treatment environments.

Table 8. Regression equations relating performance of susceptible (S) and partially resistant (PR) pearl millet forage hybrids with the average performance of all hybrids $(y)$ within each year $\times$ treatment environment $(x)$

\begin{tabular}{|c|c|c|c|c|c|}
\hline \multirow[b]{2}{*}{ Variable } & \multirow[b]{2}{*}{ Cluster } & \multirow[b]{2}{*}{ Regression equation } & \multirow{2}{*}{$\begin{array}{c}\text { Standard } \\
\text { error of } b_{1}{ }^{u}\end{array}$} & \multicolumn{2}{|c|}{ Test of significance } \\
\hline & & & & $b_{1}=1$ & $S$ versus $P R$ \\
\hline \multirow[t]{2}{*}{ Final rust severity (\%) } & Susceptible & $y=2.234+1.076 x$ & 0.027 & $\mathrm{NS}^{\mathrm{v}}$ & *** \\
\hline & Partial resistance & $y=-1.815+0.936 x$ & 0.023 & NS & \\
\hline \multirow[t]{2}{*}{ AUDPC $^{\mathrm{w}}$} & Susceptible & $y=36.456+1.168 x$ & 0.031 & $*$ & $* *$ \\
\hline & Partial resistance & $y=-29.025+0.859 x$ & 0.026 & * & \\
\hline \multirow{2}{*}{$\mathrm{DMY}^{\mathrm{x}}(\mathrm{kg} / \mathrm{ha})$} & Susceptible & $y=-830.924+1.056 x$ & 0.052 & NS & * \\
\hline & Partial resistance & $y=693.527+0.953 x$ & 0.043 & NS & \\
\hline \multirow{2}{*}{$\operatorname{IVDMD}^{\mathrm{y}}(\%)$} & Susceptible & $y=-0.133+1.243 x$ & 0.054 & $*$ & $* *$ \\
\hline & Partial resistance & $y=0.111+0.798 x$ & 0.043 & $*$ & \\
\hline \multirow[t]{2}{*}{$\operatorname{DDMY}^{\mathrm{z}}(\mathrm{kg} / \mathrm{ha})$} & Susceptible & $y=-647.254+1.094 x$ & 0.028 & $*$ & $* *$ \\
\hline & Partial resistance & $y=539.256+0.921 x$ & 0.024 & $*$ & \\
\hline
\end{tabular}

u $\mathrm{b}_{1}=$ Slope of regression line.

${ }^{v} \mathrm{NS}, *$, and $* *$ indicate nonsignificant or significance at $P=0.05$ and 0.01 , respectively.

${ }^{\mathrm{w}}$ Area under the disease progress curve.

${ }^{x}$ Dry matter yield.

y In vitro dry matter digestibility.

${ }^{z}$ Digestible dry matter yield. 
additional resistance genes, which would probably result in a cumulatively higher expression of resistance (12). Long-term durability of resistance can only be identified in retrospect; however, this resistance would provide a measure of stability to biomass production. In the event of a shift in virulence gene frequencies in the pathogen population, digestible biomass reductions would be moderated by the presence of genes for partial resistance.

\section{ACKNOWLEDGMENTS}

We thank T. Perla and J. Dillard for their technical assistance.

\section{LITERATURE CITED}

1. Burton, G. W. 1980. Registration of pearl millet inbred Tift 383 and Tifleaf 1 pearl millet. Crop Sci. 20:292.

2. Burton, G. W., and Wilson, J. P. 1995. Registration of Tift 65 parental inbred line of pearl millet. Crop Sci. 35:1244.

3. Finlay, K. W., and Wilkinson, G. N. 1963.
The analysis of adaptation in a plant-breeding programme. Aust. J. Agric. Res. 14:742-754.

4. Hanna, W. W., Wells, H. D., Burton, G. W., Hill, G. M., and Monson, W. G. 1988. Registration of 'Tifleaf 2' pearl millet. Crop Sci. 28:1023.

5. Headrick, J. M., and Pataky, J. K. 1987. Expression of partial resistance to common rust in sweet corn hybrids at various host growth stages. Phytopathology 77:454-458.

6. Ma, H., and Singh, R. P. 1996. Expression of adult resistance to stripe rust at different growth stages of wheat. Plant Dis. 80:375-379.

7. Ohm, H. W., and Shaner, G. E. 1976. Three components of slow leaf-rusting at different growth stages in wheat. Phytopathology 66:1356-1360.

8. Pannu, P. P. S., Sokhi, S. S., and Aulakh, K. S. 1996. Resistance in pearl millet against rust. Indian Phytopathol. 49:243-246.

9. Parlevliet, J. E. 1975. Partial resistance of barley to leaf rust, Puccinia hordei. I. Effect of cultivar and developmental stage on latent period. Euphytica 24:21-27.

10. Sokhi, S. S., and Singh, B. B. 1984. Components of slow rusting in pearl millet infected with Puccinia penniseti. Indian J. Mycol.
Plant Pathol. 14:190-192.

11. Tapsoba, H., and Wilson, J. P. 1996. Pathogenic variation in Puccinia substriata var. indica in the southeastern United States and screening for resistance in pearl millet germ plasm. Plant Dis. 80:395-397.

12. Wilson, J., and Shaner, G. 1989. Individual and cumulative effects of long latent period and low infection type reactions to Puccinia recondita in triticale. Phytopathology 79:101-108.

13. Wilson, J. P. 1994. Field and greenhouse evaluations of pearl millet for partial resistance to Puccinia substriata var. indica. Plant Dis. 78:1202-1205.

14. Wilson, J. P. 1997. Inheritance of partial rust resistance in pearl millet. Plant Breed. 116:239-243.

15. Wilson, J. P., Gates, R. N., and Hanna, W. W. 1991. Effect of rust on yield and digestibility of pearl millet forage. Phytopathology 81:233-236.

16. Wilson, J. P., and Hanna, W. W. 1992. Effects of gene and cytoplasm substitutions in pearl millet on leaf blight epidemics and infection by Pyricularia grisea. Phytopathology 82:839-842.

17. Wilson, J. P., Hanna, W. W., and Gascho, G. J. 1996. Pearl millet grain yield loss from rust infection. J. Prod. Agric. 9:543-545. 